\title{
Status of Optical Coatings for the National Ignition Facility
}

C.J. Stolz, C. Weinzapfel, G.T. Rogowski, D. Smith, A. Rigatti, J. Oliver, J. Taniguchi, M. von Gunten, R. Bevis, M. Smith and V. Ivan

This article was submitted to Optical Interface Coatings Topical Conference, Banff, Alberta, Canada, July 13-20, 2001

U.S. Department of Energy

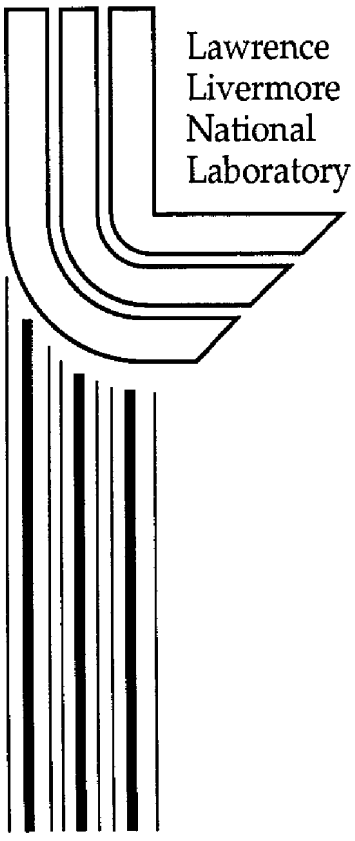

March 5, 2001

Livermore

National

Laboratory 


\section{DISCLAIMER}

This document was prepared as an account of work sponsored by an agency of the United States Government. Neither the United States Government nor the University of California nor any of their employees, makes any warranty, express or implied, or assumes any legal liability or responsibility for the accuracy, completeness, or usefulness of any information, apparatus, product, or process disclosed, or represents that its use would not infringe privately owned rights. Reference herein to any specific commercial product, process, or service by trade name, trademark, manufacturer, or otherwise, does not necessarily constitute or imply its endorsement, recommendation, or favoring by the United States Government or the University of California. The views and opinions of authors expressed herein do not necessarily state or reflect those of the United States Government or the University of California, and shall not be used for advertising or product endorsement purposes.

This is a preprint of a paper intended for publication in a journal or proceedings. Since changes may be made before publication, this preprint is made available with the understanding that it will not be cited or reproduced without the permission of the author.

This report has been reproduced directly from the best available copy.

Available electronically at http://www.doc.gov/bridge

Available for a processing fee to U.S. Department of Energy

And its contractors in paper from

U.S. Department of Energy

Office of Scientific and Technical Information

P.O. Box 62

Oak Ridge, TN 37831-0062

Telephone: (865) 576-8401

Facsimile: (865) 576-5728

E-mail: reports@adonis.osti.gov

Available for the sale to the public from

U.S. Department of Commerce

National Technical Information Service

5285 Port Royal Road

Springfield, VA 22161

Telephone: (800) 553-6847

Facsimile: (703) 605-6900

E-mail: orders@ntis.fedworld.gov

Online ordering: http:/ / www.ntis.gov/ordering.htm

\section{OR}

Lawrence Livermore National Laboratory

Technical Information Department's Digital Library

http: / / www.llnl.gov/tid/Library.html 


\title{
Status of Optical Coatings for the National Ignition Facility
}

\author{
Christopher J. Stolz, Carolyn Weinzapfel, and Gregory T. Rogowski \\ Lawrence Livermore National Laboratory, P.O. Box 808, L-487, Livermore, CA 94550
}

(925) 422-3562, e-mail: stolz1@llnl.gov

Doug Smith, Amy Rigatti, Jim Oliver, and Jason Taniguchi

Laboratory for Laser Energetics, University of Rochester, 250 E. River Rd., Rochester NY 14623

Marc von Gunten, Ron Bevis, Michelle Smith, and Vladimir Ivan

Spectra Physics, Inc., 1330 Terra Bella Ave., Mountain View, CA 94043

\section{Abstract}

Optical coatings are a crucial part of the pulse trapping and extraction in the NIF multipass amplifiers. Coatings also steer the 192 beams from four linear arrays to four converging cones entering the target chamber. There are a total of 1600 physical vapor deposited coatings on NIF consisting of 576 mirrors within the multipass cavity, 192 polarizers that work in tandem with a Pockels cell to create an optical switch, and 832 transport mirrors. These optics are of sufficient size so that they are not aperture-limiting for the $40-\mathrm{cm} \times 40 \mathrm{~cm}$ beams over an incident range of 0 to 56.4 degrees. These coatings must withstand laser fluences up to $25 \mathrm{~J} / \mathrm{cm}^{2}$ at $1053 \mathrm{~nm}(1 \omega)$ and 3-ns pulse length and are the $1 \omega$ fluence-limiting component on NIF. The coatings must have a minimal impact on the beam wavefront and phase to maintain beam focusability, minimize scattered loss, and minimize nonlinear damage mechanisms. This is achieved by specifications ranging from $<50 \mathrm{MPa}$ coating stress, $<1 \%$ coating nonuniformity, $<4 \AA \AA$ RMS surface roughness, and a PSD specification to control the amplitude of periodic spatial frequencies. Finally, the primary mission of optical coatings is efficient beam steering so reflection and transmission losses are specified as $\mathrm{R}>99.5 \%$ and $>99 \%$ for mirrors and polarizers, respectively, and $\mathrm{T}>98 \%$ for polarizers.

\section{Introduction}

Successful demonstration of crucial NIF technologies in 1995 on Beamlet, a single beam prototype, the Inertial Confinement Fusion (ICF) program embarked on development of optical technologies. The primary objective was to enable the manufacture of the 192 beam NIF laser at lower unit costs than Beamlet, with accelerated fabrication rates to meet the NIF assembly schedule, and at higher quality to meet the stringent user community demands.

The coating development program, lasting about four years, focussed on improving source stability, process monitoring, damage threshold, stress control, and chamber production readiness. A one-year facilitization phase addressed large-aperture post-deposition metrology and manufacturing equipment. Currently the coating vendors are in Pilot production coating the first $\sim 10 \%$ of NIF optics.

\section{Requirements}

In the technology center of optical coatings, the primary objectives were many; identification of the best deposition process for NIF requirements including high laser damage threshold, scalability to meter dimensions, low coating stress, relatively low loss, and good uniformity. Two primary deposition methods were identified, Physical Vapor Deposition (PVD) and Ion Beam Sputtering (IBS). PVD coatings have supported the ICF programs for decades and were successfully used on Beamlet. An example of the scale of a PVD coating chamber used for ICF at Spectra-Physics is in Fig. 1. Although sputtered coatings offer some significant advantages over PVD coatings such as extremely low loss and stability regardless of operating environment, scalability proved to be formidable particularly for high damage thresholds in the 3-10 ns regime [1]. Scalability of spectral uniformity of meter-sized optics also proved to be challenging. Therefore, PVD coatings via reactive electron-beam deposition became the coating process of choice. 


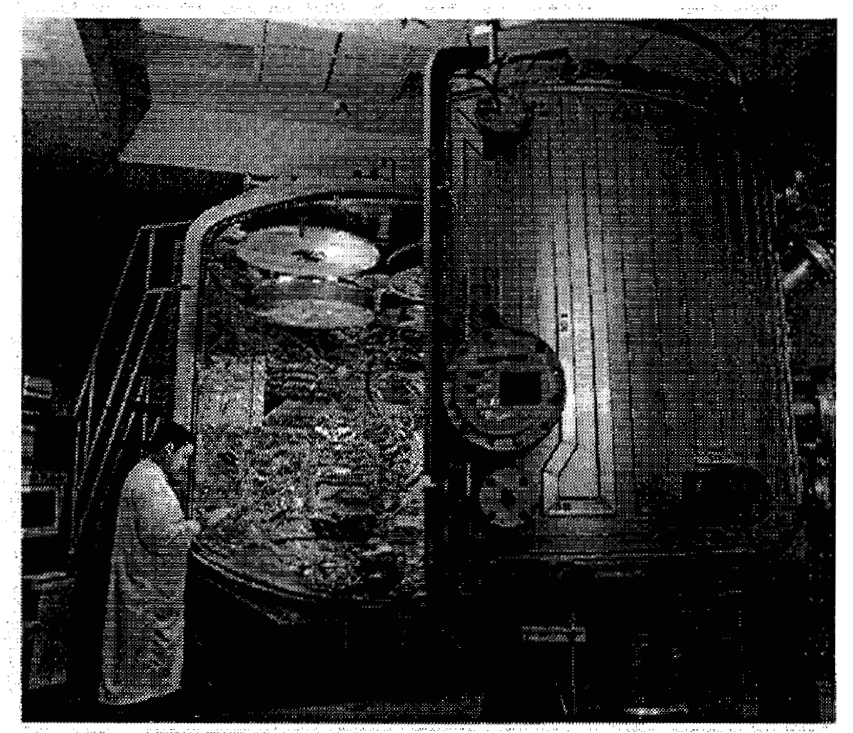

The largest process modification versus what was used on Beamlet was the use of hafnium metal instead of hafnia, an oxide, as the starting material [2]. This process change reduced the defect density by 4 $10 \times$ for fewer laser damage initiation sites, and improved deposition plume stability to improve layer thickness control for higher spectral yields. Coating stress has been minimized for the humidity of the operating environment by turning the background oxygen pressure during silica deposition [3-4]. Laser damage thresholds were increased by understanding the causes of different damage morphologies including plasma scalds, pits, flat-bottom pits, and delaminations by process design modifications [5]. Coating uniformity was controlled by masking which proved particularly challenging for the planetary configuration at one of the coating vendors [6].

Fig. 1 PVD coating system (A2) at Spectra-Physics for coating four NIF optics per run.

After development, a facilitization program was launched in 1999 to implement the process modifications into production facilities. This phase included facility modifications and equipment installations ranging from semiautomated ultrasonic cleaning stations, chamber readiness improvements including new controllers, and improved diagnostics. Metrology tools were also installed including an 18 " $1 \omega$ phase interferometer installed in a humiditycontrolled environment illustrated in Fig. 2; laser based photometer illustrated in Fig. 3, laser damage testers, and laser conditioning stations illustrated in Fig. 4.

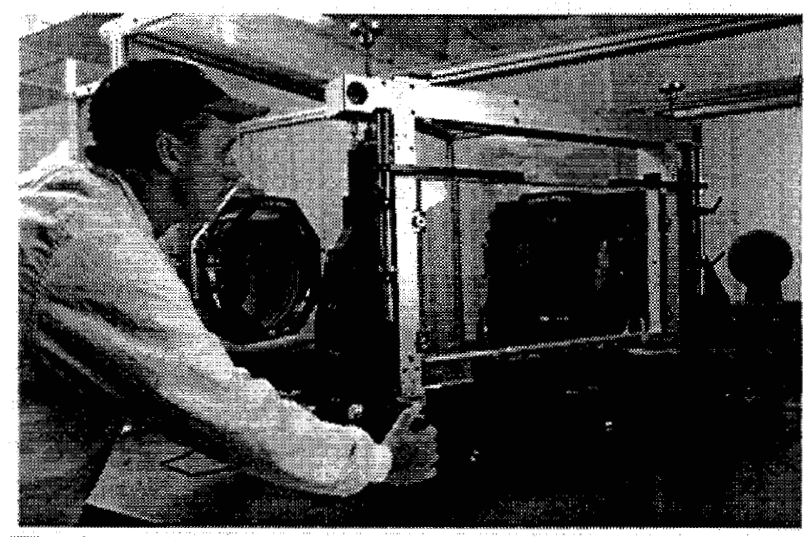

Fig. 2. $1 \omega 18$ " phase measuring interferometer controlled environment.

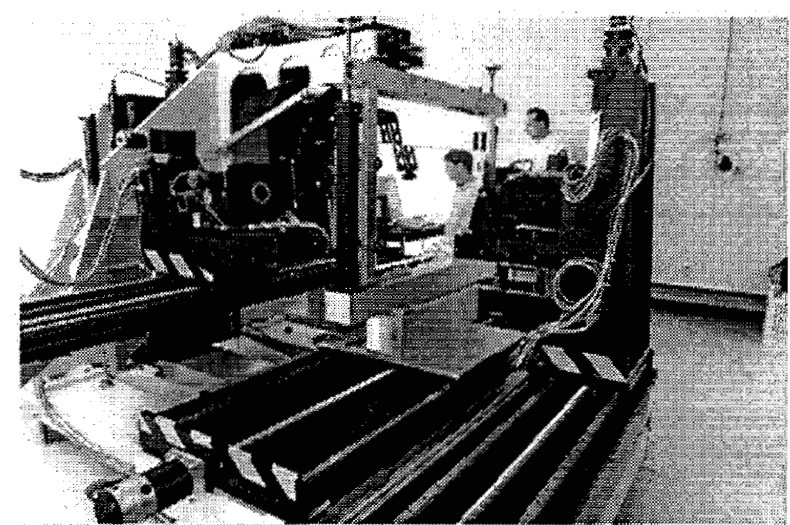

Fig. 3. 1, 2, and $3 \omega$ scanning laser in humidity photometer

Current NIF coating vendors are in a Pilot production program to identify and resolve manufacturing issues as part of production start up. With an expected production program of approximately 24 large optics per month over the next seven years, coating vendors will coat $460 \mathrm{~m}^{2}$ of high-damage-threshold precision coatings on 100 tons of BK-7 material with yields expected to exceed $90 \%$. 


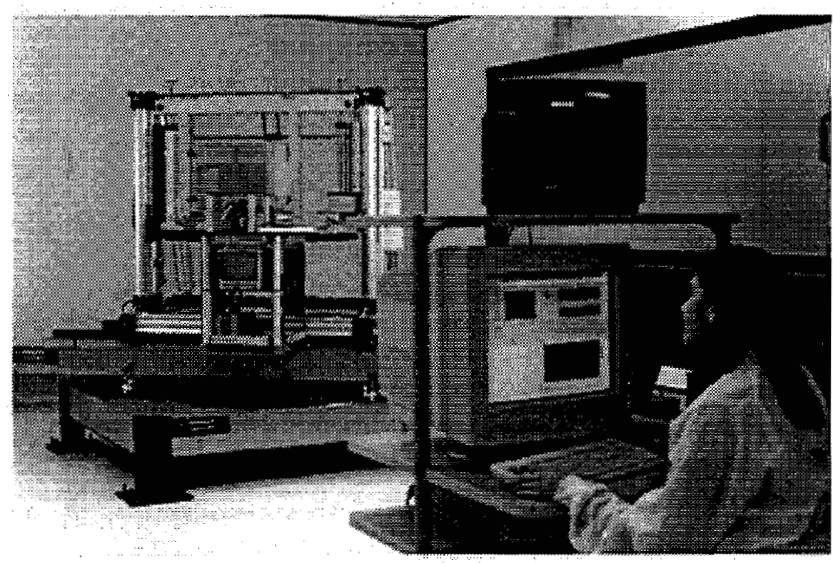

Fig. 4. Two laser conditioning stations are at each coating vendor to raster scan all high fluence coatings past a $1-\mathrm{mm}$ diameter, $1064 \mathrm{~nm}$ laser beam.

\section{Conclusion}

A deposition process has been developed for manufacturing repeatable high fluence coatings, $2-4 \times$ higher than required for Nova, the last LLNL fusion laser. Coating vendors are facilitized to meet the capacity and metrological requirements for NIF. Pilot production has just begun to resolve production start up issues. NIF production will occur until 2007.

\section{References}

[1] Stolz, C. J., Génin, F. Y., Kozlowski, M. R., Long, D., Lalazari, R., Wu, Z. L., and Kuo, P. K., "Influence of microstructure on laser damage threshold of IBS coatings," in Laser-Induced Damage in Optical Materials: 1995, H. E. Bennett, A. H. Guenther, M. R. Kozlowski, B. E. Newnam, and M. J. Soileau, eds., Proc. SPIE 2714, 351-358 (1996).

[2] Stolz, C. J., Sheehan, L. M., Von Gunten, M. K., Bevis, R. P., and Smith, D. J., "The advantages of evaporation of hafnium in a reactive environment to manufacture high damage threshold multilayer coatings by electron-beam deposition", in Advances in Optical Interference Coatings, C. Amra and H. A. Macleod, eds., Proc. Soc. Photo-Opt. Instrum. Eng. 3738, 318-324 (1999).

[3] Anzellotti, J. F., Smith, D. J., Sczupak, R. J., and Chrzan, Z. R., "Stress and environmental shift characteristics of $\mathrm{HfO}_{2} / \mathrm{SiO}_{2}$ multilayer coatings," in Laser-Induced Damage in Optical Materials: 1996, $\mathrm{H}$. E. Bennett, A. H. Guenther, M. R. Kozlowski, B. E. Newnam, and M. J. Soileau, eds., Proc. SPIE 2966, 258264 (1996).

[4] Leplan, H., Geenen, B., Robic, J. Y., and Pauleau, Y., "Residual stresses in evaporated silicon dioxide thin films: Correlation with deposition parameters and aging behavior," J. Appl. Phys. 78, 962-968 (1995).

[5] Genin, F. Y., and Stolz, C. J., "Morphologies of laser-induced damage in hafnia-silica multilayer mirror and polarizer coatings," in Third International Workshop on Laser Beam and Optics Characterization, Michel Morin, Adolf, editors., Proc. SPIE 2870, 439-448 (1996).

[6] Smith, D. J., Staley, A., Eriksson, R., and Algar, G., "Counter-rotating planetary design for large rectangular substrates," in 1998 Proceedings of the Annual Conference of the Society of Vacuum Coaters, 193-196 (1998).

This work was performed under the auspices of the U.S. Department of Energy by the University of California, Lawrence Livermore National Laboratory under Contract No. W-7405-Eng-48. 